\title{
Asthma and risk of myelodysplastic syndromes: a population-based cohort study
}

\author{
Henrik Frederiksen ${ }^{\star} 1,2$, Dóra Körmendiné Farkas², Erzsébet Horváth-Puhó ${ }^{2}$ Jan M Nørgaard ${ }^{3}$, \\ Mette Nørgaard ${ }^{2}$ and Henrik T Sørensen ${ }^{2}$ \\ ${ }^{1}$ Department of Haematology, Odense University Hospital, Odense, Denmark; ${ }^{2}$ Department of Clinical Epidemiology, Aarhus \\ University Hospital, Aarhus, Denmark and ${ }^{3}$ Department of Haematology, Aarhus University Hospital, Aarhus, Denmark
}

Background: Risk factors for the development of myelodysplastic syndromes (MDS) include age, exposure to ionising radiation, and cytotoxic drug treatment. Recently, asthma also has been suggested as a risk factor for MDS.

Methods: We undertook this nationwide population-based cohort study on patients with a first-time hospital-based asthma diagnosis during 2002-2013 and followed them for the development of MDS/chronic myelomonocytic leukaemia (CMML).

Results: We identified 75995 patients with incident asthma and no previous MDS/CMML diagnosis. Seventy-eight patients subsequently developed MDS and nine patients developed CMML during 402892 person-years. The cumulative risks of developing MDS/CMML among asthma patients were $0.02 \%$ (95\% Cl: $0.01-0.04 \%$ ) and $0.07 \%$ (95\% Cl: $0.05-0.09 \%$ ) during the first year and the first five years of follow-up, respectively. The standardised incidence ratio of MDS/CMML among asthma patients overall was 1.6 (95\% Cl: 1.3-2.0) with little variation across subgroups.

Conclusions: Asthma may be a risk factor for the development of MDS/CMML.

Myelodysplastic syndromes (MDS) constitute a group of related clonal hematopoietic disorders (Swerdlow et al, 2008). Risk factors for MDS include age, ionising radiation, smoking, occupational exposures, and cytotoxic drugs (Nisse et al, 1995; Andersen et al, 1998; Bjork et al, 2000; Dalamaga et al, 2002; Smith et al, 2003).

In a cohort of 22601 women aged 55-59, self-reported asthma in 1997 was associated with a two-fold higher risk of MDS during the median follow-up of 14.8 years $(\mathrm{RR}=2.0$ (95\% confidence interval (CI): 1.0-4.6)). Outcomes were MDS and other incident haematological malignancies identified in the State Health Registry of Iowa (Linabery et al, 2014). Although the underlying mechanism is unknown, immune dysregulation in MDS is evident, as some subtypes respond to the treatment with immunosuppressive or immunomodulatory agents (Saunthararajah et al, 2003; List et al, 2005; Mollgard et al, 2011; Duong et al, 2012). Some MDS patients also exhibit immune-mediated conditions such as vasculitis (Farah et al, 2010). We investigated the association between asthma and MDS/chronic myelomonocytic leukaemia (CMML) in a large cohort of adults.

\section{MATERIALS AND METHODS}

We conducted this cohort study using the Danish National Patient Registry (DNPR) and the Civil Registration System (CRS; Schmidt et al, 2014; Schmidt et al, 2015). The DNPR contains information on all inpatient discharges from hospitals since 1977, and on outpatient clinic and emergency department visits since 1995. The DNPR records patients' civil registration numbers, dates of outpatient visits, hospitalisations, and up to 20 diagnoses coded by physicians according to the WHO's International Classification of Diseases, Eighth Revision (ICD-8) until 1993 and Tenth Revision (ICD-10) thereafter. We identified all patients aged $\geqslant 18$ years with a first-time hospital-based diagnosis of asthma (ICD-10 codes J45-46) in the DNPR during 2002-2013 (Byrjalsen et al, 2014) and subsequent diagnoses of MDS or CMML (MDS code: D46, CMML code: C93). We excluded patients whose MDS/CMML diagnosis preceded their asthma diagnosis. The CRS has recorded date of birth, sex, and vital status of all Danish residents since 1968. Follow-up for MDS/CMML began on the date of the asthma

*Correspondence: Dr H Frederiksen; E-mail: hef@dadlnet.dk

Received 12 July 2016; revised 25 October 2016; accepted 3 November 2016; published online 29 November 2016

(c) 2017 Cancer Research UK. All rights reserved 0007-0920/17 
diagnosis and continued until death, emigration, or 30 November 2013, whichever came first. Inclusion of cohort members began in 2002 after introduction of the WHO classification of MDS and CMML (Swerdlow et al, 2008; Dinmohamed et al, 2014).

We calculated the risk of MDS/CMML after an asthma diagnosis, treating death as a competing risk. For each calendar year, expected numbers of MDS/CMML in the DNPR were calculated by multiplying the person-years of observation by the appropriate nationwide age-specific and gender-specific incidence rates, with 5-year age groups. Standardised incidence ratios (SIRs) - the ratio of observed numbers of incident cancers to those expected - were used as measures of the relative risk.

We computed 95\% CIs for the SIRs based on the assumption that the observed number of cases followed a Poisson distribution. Exact 95\% CIs were used when the observed number of MDS/ CMML cases was $<10$; otherwise Byar's approximation was used.

\section{RESULTS}

We identified 75995 patients with incident asthma and no previous diagnosis of MDS or CMML. Their median age was 48.9 years and median follow-up time was 5.0 years (IQR: 2.2-8.2 years). Seventy-eight patients developed MDS and nine patients developed CMML during 402892 person-years of follow-up. During 1, 5, and 10 years of follow-up, the cumulative risks of developing MDS/CMML for asthma patients were 0.02\% (95\% CI: $0.01-0.04 \%), 0.07 \%$ (95\% CI: $0.05-0.09 \%)$, and $0.12 \%$ (95\% CI: $0.09-0.15 \%)$, respectively.

Asthma patients were at increased risk of developing MDS/ CMML (SIR 1.6 (95\% CI: 1.3-2.0); Table 1). SIR estimates across subgroups were similar (Table 1). When MDS and CMML patients were analysed separately, the SIR for MDS was identical to the overall SIR (1.6 (95\% CI: 1.3-2.0)), whereas the SIR for CMML was imprecise (1.4 (95\% CI: 0.6-2.6)) due to low numbers. The association was observed in all subgroups, as well as among patients without concurrent COPD (Table 1). As cancer treatment is a risk factor for MDS, we repeated our analyses excluding asthma patients with a previous cancer diagnosis, censoring follow-up if patients developed a cancer diagnosis before MDS/CMML, and also treating both the cancer and death as competing risks. These analyses resulted in virtually identical SIR estimates (data not shown).

\section{DISCUSSION}

We found an increased risk of MDS/CMML among patients with an asthma diagnosis. These findings are in line with the study by Linabery et al (2014). They reported no association between allergic diseases other than asthma and haematological malignancies. In a review of the previous studies, providing estimates of the association between allergic conditions and haematological myeloid neoplasms, Wang and Diepgen (2005) reported imprecise risk estimates around unity. In a case-control study that specifically included MDS patients and examined self-reported allergic conditions other than asthma, no differences in frequencies of allergies were observed between the MDS patients and their controls (Pekmezovic et al, 2006).

The mechanism linking asthma to MDS/CMML remains unknown. Although, epigenetic modifications are common to MDS/CMML and asthma (Yang and Schwartz, 2012; Bravo et al, 2014), they are unlikely to explain the association as the hallmark of MDS/CMML is clonal proliferation of neoplastic cells with subsequent epigenetic modifications, whereas asthma is a nonclonal disease.

Most previous studies of allergic conditions and risk of haematological cancers have focused on lymphoid malignancies (Wang and Diepgen, 2005; Turner et al, 2006; Melbye et al, 2007), with conflicting results. Some studies have found that allergic conditions and specific IgE titres were associated with the decreased risk of lymphoid haematological malignancies, (Wang and Diepgen, 2005), but one study suggested that these findings may be attributed to reverse causality, that is, immunological

\begin{tabular}{|c|c|c|c|c|}
\hline Patient characteristics ( $n$ ) & $\begin{array}{l}\text { Person-years of follow-up } \\
\text { among patients with asthma }\end{array}$ & $\begin{array}{l}\text { Asthma patients with } \\
\text { MDS or CMML (n) }\end{array}$ & $\begin{array}{c}\text { Expected MDS/CMML } \\
\text { cases }(n)\end{array}$ & SIR $(95 \% \mathrm{Cl})$ \\
\hline $\begin{array}{l}\text { All (75 995) } \\
\text { Women (47 385) } \\
\text { Men (28 610) }\end{array}$ & $\begin{array}{l}402892 \\
249358 \\
153533\end{array}$ & $\begin{array}{l}87 \\
47 \\
40\end{array}$ & $\begin{array}{l}54.6 \\
26.5 \\
28.1\end{array}$ & $\begin{array}{l}1.6(1.3-2.0) \\
1.8(1.3-2.4) \\
1.4(1.0-1.9)\end{array}$ \\
\hline $\begin{array}{l}\text { Age at asthma diagnosis (years) } \\
\text { 18-44 (32712) } \\
45-70(31187) \\
71+(12096)\end{array}$ & $\begin{array}{c}192487 \\
165779 \\
44626\end{array}$ & $\begin{array}{r}6 \\
41 \\
40\end{array}$ & $\begin{array}{c}2.7 \\
24.2 \\
27.7\end{array}$ & $\begin{array}{l}2.2(0.8-4.9) \\
1.7(1.2-2.3) \\
1.4(1.0-2.0)\end{array}$ \\
\hline $\begin{array}{l}\text { Year of asthma diagnosis } \\
\text { 2002-2007 (38 413) } \\
2008-2013 \text { (37 582) }\end{array}$ & $\begin{array}{l}300173 \\
102719\end{array}$ & $\begin{array}{l}60 \\
27\end{array}$ & $\begin{array}{l}36.0 \\
18.6\end{array}$ & $\begin{array}{l}1.7(1.3-2.2) \\
1.5(1.0-2.1)\end{array}$ \\
\hline $\begin{array}{l}\text { Follow-up time } \\
\begin{array}{l}0-1 \text { yr (75 995) } \\
2-5 \text { yrs (66 393) } \\
6-10 \text { yrs (37 644) } \\
>10 \text { yrs (9921) }\end{array}\end{array}$ & $\begin{array}{c}70645 \\
205764 \\
116848 \\
9634\end{array}$ & $\begin{array}{c}21 \\
35 \\
24 \\
7\end{array}$ & $\begin{array}{c}7.7 \\
24.2 \\
19.1 \\
3.6\end{array}$ & $\begin{array}{l}2.7(1.7-4.2) \\
1.5(1.0-2.0) \\
1.3(0.8-1.9) \\
1.9(0.8-4.0)\end{array}$ \\
\hline $\begin{array}{l}\text { Hospital contact type } \\
\text { Inpatient admission (26 170) } \\
\text { Outpatient specialist clinic visit only (42 497) } \\
\text { Emergency room only (7328) }\end{array}$ & $\begin{array}{c}131407 \\
229960 \\
41525\end{array}$ & $\begin{array}{l}41 \\
35 \\
11\end{array}$ & $\begin{array}{c}22.6 \\
27.4 \\
4.6\end{array}$ & $\begin{array}{l}1.8(1.3-2.5) \\
1.3(0.9-1.8) \\
2.4(1.2-4.3)\end{array}$ \\
\hline $\begin{array}{l}\text { Presence of chronic obstructive pulmonary } \\
\text { disease (COPD) } \\
\text { Asthma and COPD (10 829) } \\
\text { Asthma without COPD }(65166)\end{array}$ & $\begin{array}{c}44941 \\
357950\end{array}$ & $\begin{array}{l}28 \\
59\end{array}$ & $\begin{array}{l}13.9 \\
40.7\end{array}$ & $\begin{array}{l}2.0(1.3-2.9) \\
1.5(1.1-1.9)\end{array}$ \\
\hline
\end{tabular}


response to IgE-specific allergens may be compromised among patients with the developing lymphomas (Melbye et al, 2007).

Despite its large size, and complete follow-up, our study has limitations. We included only asthma diagnosed in hospital-based settings. Some asthma patients may be diagnosed and followed by their general practitioner without a hospital contact (Hanania et al, 2011). However, asthma patients above 65 years of age ( $\sim 10 \%$ of prevalent asthma cases) are most likely to be referred to hospitalbased care (Hanania et al, 2011). As the incidence of MDS/CMML increases with age, (Dinmohamed et al, 2014) a larger proportion of MDS/CMML patients with a preceding asthma diagnosis would have had a hospital-based asthma diagnosis. During the first year following asthma diagnosis, the SIR estimate for MDS/CMML development was higher than in the following years. Heightened diagnostic effort probably explains part of the association in the short term. However, the increased risk was remarkably persistent many years after an asthma diagnosis.

In the DNPR, the completeness of the asthma diagnosis in conscripts has been found to be 0.44 and the specificity to be 0.98 (Jensen et al, 2010). Asthma patients with a hospital referral, however could have a higher risk of MDS/CMML than asthma patients treated only by general practitioners due to potentially, more severe asthma and higher levels of comorbidity. As well, because of our study's registry-based design, we lacked detailed patient-specific information, such as smoking status. Still, when we used a concurrent COPD diagnosis as a proxy for smoking, we observed the association between asthma and MDS/CMML among the asthma patients without COPD.

We conclude that asthma may be a risk factor for the development of MDS/CMML.

\section{AUTHOR CONTRIBUTIONS}

HF and HTS conceived the idea for the study. DKF and EH-P performed the statistical analyses. HF wrote the first draft of the manuscript and all authors participated in writing subsequent drafts.

\section{CONFLICT OF INTEREST}

The authors declare no conflict of interest.

\section{REFERENCES}

Andersen MK, Johansson B, Larsen SO, Pedersen-Bjergaard J (1998) Chromosomal abnormalities in secondary MDS and AML. Relationship to drugs and radiation with specific emphasis on the balanced rearrangements. Haematologica 83(6): 483-488.

Bjork J, Albin M, Mauritzson N, Stromberg U, Johansson B, Hagmar L (2000) Smoking and myelodysplastic syndromes. Epidemiology 11(3): 285-291.

Bravo GM, Lee E, Merchan B, Kantariian HM, Garcia-Manero G (2014) Integrating genetics and epigenetics in myelodysplastic syndromes: advances in pathogenesis and disease evolution. Br J Haematol 166(5): 646-659.

Byrjalsen A, Froslev T, Telen Andersen AB, Olsen M, Sorensen HT (2014) Use of corticosteroids during pregnancy and risk of asthma in offspring: a nationwide Danish cohort study. BMJ Open 4(6): e005053.

Dalamaga M, Petridou E, Cook FE, Trichopoulos D (2002) Risk factors for myelodysplastic syndromes: a case-control study in Greece. Cancer Causes Control 13(7): 603-608.

Dinmohamed AG, Visser O, van NY, Huijgens PC, Sonneveld P, van de Loosdrecht AA, Jongen-Lavrencic M (2014) Trends in incidence, initial treatment and survival of myelodysplastic syndromes: a population-based study of 5144 patients diagnosed in the Netherlands from 2001 to 2010. Eur J Cancer 50(5): 1004-1012.

Duong VH, Komrokji RS, List AF (2012) Efficacy and safety of lenalidomide in patients with myelodysplastic syndrome with chromosome $5 \mathrm{q}$ deletion. Ther Adv Hematol 3(2): 105-116.

Farah C, Bulai LC, Jegu J, Paul C, Viraben R, Lamant L, Delavigne K, Adoue D, Laurent G, Beyne RO (2010) Prevalence and prognostic value of cutaneous manifestations in patients with myelodysplastic syndrome. $J$ Eur Acad Dermatol Venereol 24(10): 1171-1175.

Hanania NA, King MJ, Braman SS, Saltoun C, Wise RA, Enright P, Falsey AR, Mathur SK, Ramsdell JW, Rogers L, Stempel DA, Lima JJ, Fish JE, Wilson SR, Boyd C, Patel KV, Irvin CG, Yawn BP, Halm EA, Wasserman SI, Sands MF, Ershler WB, Ledford DK (2011) Asthma in the elderly: Current understanding and future research needs-a report of a National Institute on Aging (NIA) workshop. J Allergy Clin Immunol 128(3 Suppl): S4-24.

Jensen AO, Nielsen GL, Ehrenstein V (2010) Validity of asthma diagnoses in the Danish National Registry of Patients, including an assessment of impact of misclassification on risk estimates in an actual dataset. Clin Epidemiol 2: 67-72.

Linabery AM, Prizment AE, Anderson KE, Cerhan JR, Poynter JN, Ross JA (2014) Allergic diseases and risk of hematopoietic malignancies in a cohort of postmenopausal women: a report from the Iowa Women's Health Study. Cancer Epidemiol Biomarkers Prev 23(9): 1903-1912.

List A, Kurtin S, Roe DJ, Buresh A, Mahadevan D, Fuchs D, Rimsza L, Heaton R, Knight R, Zeldis JB (2005) Efficacy of lenalidomide in myelodysplastic syndromes. N Engl J Med 352(6): 549-557.

Melbye M, Smedby KE, Lehtinen T, Rostgaard K, Glimelius B, Munksgaard L, Schollkopf C, Sundstrom C, Chang ET, Koskela P, Adami HO, Hjalgrim H (2007) Atopy and risk of non-Hodgkin lymphoma. J Natl Cancer Inst 99(2): 158-166.

Mollgard L, Saft L, Treppendahl MB, Dybedal I, Norgaard JM, Astermark J, Ejerblad E, Garelius H, Dufva IH, Jansson M, Jadersten M, Kjeldsen L, Linder O, Nilsson L, Vestergaard H, Porwit A, Gronbaek K, HellstromLindberg E (2011) Clinical effect of increasing doses of lenalidomide in high-risk myelodysplastic syndrome and acute myeloid leukemia with chromosome 5 abnormalities. Haematologica 96(7): 963-971.

Nisse C, Lorthois C, Dorp V, Eloy E, Haguenoer JM, Fenaux P (1995) Exposure to occupational and environmental factors in myelodysplastic syndromes. Preliminary results of a case-control study. Leukemia 9(4): 693-699.

Pekmezovic T, Suvajdzic VN, Kisic D, Grgurevic A, Bogdanovic A, Gotic M, Bakrac M, Brkic N (2006) A case-control study of myelodysplastic syndromes in Belgrade (Serbia Montenegro). Ann Hematol 85(8): 514-519.

Saunthararajah Y, Nakamura R, Wesley R, Wang QJ, Barrett AJ (2003) A simple method to predict response to immunosuppressive therapy in patients with myelodysplastic syndrome. Blood 102(8): 3025-3027.

Schmidt M, Pedersen L, Sorensen HT (2014) The Danish Civil Registration System as a tool in epidemiology. Eur J Epidemiol 29(8): 541-549.

Schmidt M, Schmidt SA, Sandegaard JL, Ehrenstein V, Pedersen L, Sorensen HT (2015) The Danish National Patient Registry: a review of content, data quality, and research potential. Clin Epidemiol 7: 449-490.

Smith SM, Le Beau MM, Huo D, Karrison T, Sobecks RM, Anastasi J, Vardiman JW, Rowley JD, Larson RA (2003) Clinical-cytogenetic associations in 306 patients with therapy-related myelodysplasia and myeloid leukemia: the University of Chicago series. Blood 102(1): 43-52.

Swerdlow SH, Campo E, Harris NL, Jaffe ES, Pileri SA, Stein H, Thiele J, Vardiman JW (2008) WHO classification of tumours of haematopoietic and lymphoid tissues. International Agency for Research on Cancer (IARC): Lyon.

Turner MC, Chen Y, Krewski D, Ghadirian P (2006) An overview of the association between allergy and cancer. Int J Cancer 118(12): 3124-3132.

Wang H, Diepgen TL (2005) Is atopy a protective or a risk factor for cancer? A review of epidemiological studies. Allergy 60(9): 1098-1111.

Yang, Schwartz DA (2012) Epigenetic mechanisms and the development of asthma. J Allergy Clin Immunol 130(6): 1243-1255.

This work is published under the standard license to publish agreement. After 12 months the work will become freely available and the license terms will switch to a Creative Commons AttributionNonCommercial-Share Alike 4.0 Unported License. 